\title{
A low membrane lipid phase transition temperature is associated with a high cryotolerance of Lactobacillus delbrueckii subspecies bulgaricus CFL1
}

\author{
J. Gautier, ${ }^{\dagger} \dagger$ S. Passot, $\dagger^{*}$ C. Pénicaud, ${ }^{*} \dagger$ H. Guillemin, ${ }^{*} \dagger$ S. Cenard, ${ }^{\star} \dagger$ P. Lieben, ${ }^{*} \dagger$ and F. Fonseca ${ }^{*} \dagger^{1}$ \\ *INRA, UMR782, Génie et Microbiologie des Procédés Alimentaires, F-78850 Thiverval-Grignon, France \\ †AgroParisTech, UMR782, Génie et Microbiologie des Procédés Alimentaires, F-78850 Thiverval-Grignon, France
}

\begin{abstract}
The mechanisms of cellular damage that lactic acid bacteria incur during freeze-thaw processes have not been elucidated to date. Fourier transform infrared spectroscopy was used to investigate in situ the lipid phase transition behavior of the membrane of Lactobacillus delbrueckii ssp. bulgaricus CFL1 cells during the freeze-thaw process. Our objective was to relate the lipid membrane behavior to membrane integrity losses during freezing and to cell-freezing resistance. Cells were produced by using 2 different culture media: de Man, Rogosa, and Sharpe (MRS) broth (complex medium) or mild whey-based medium (minimal medium commonly used in the dairy industry), to obtain different membrane lipid compositions corresponding to different recovery rates of cell viability and functionality after freezing. The lipid membrane behavior studied by Fourier transform infrared spectroscopy was found to be different according to the cell lipid composition and cryotolerance. Freeze-resistant cells, exhibiting a higher content of unsaturated and cyclic fatty acids, presented a lower lipid phase transition temperature (Ts) during freezing $\left(\mathrm{Ts}=-8^{\circ} \mathrm{C}\right)$, occurring within the same temperature range as the ice nucleation, than freeze-sensitive cells $\left(\mathrm{Ts}=+22^{\circ} \mathrm{C}\right)$. A subzero value of lipid phase transition allowed the maintenance of the cell membrane in a relatively fluid state during freezing, thus facilitating water flux from the cell and the concomitant volume reduction following ice formation in the extracellular medium. In addition, the lipid phase transition of freeze-resistant cells occurred within a short temperature range, which could be ascribed to a reduced number of fatty acids, representing more than $80 \%$ of the total. This short lipid phase transition could be associated with a limited phenomenon of lateral phase separation and membrane permeabilization. This work highlights that membrane phase transitions occurring during freeze-thawing play a fundamental role
\end{abstract}

Received March 13, 2013.

Accepted May 15, 2013.

${ }^{1}$ Corresponding author: fonseca@grignon.inra.fr in the cryotolerance of $L b$. delbrueckii ssp. bulgaricus CFL1 cells.

Key words: lactic acid bacteria, cryoresistance, fatty acid, membrane lipid phase transition

\section{INTRODUCTION}

Concentrates of lactic acid bacteria (LAB) are widely used in the food industry as starters for manufacturing cheeses, fermented milks, meats, vegetables, as well as for health-benefit products (probiotics). Freezing and storage at low temperatures $\left(-50^{\circ} \mathrm{C}\right.$ ) are commonly applied to preserve the viability of concentrates while maintaining their technological properties (acidifying activity, production of aroma compounds, and contribution to product texture). Lactobacillus delbrueckii ssp. bulgaricus CFL1, a gram-positive LAB commonly used in fermented milk products is particularly sensitive to freezing, which generally leads to a low recovery rate of its technological properties upon thawing (Fonseca et al., 2000; Fonseca et al., 2003; Rault et al., 2010).

Direct cell injury following freezing has been explained by the 2-factor hypothesis of Mazur et al. (1972). This hypothesis suggests that, at low cooling rates, ice crystals are formed outside the cell, resulting in an increase in the solute concentration in the extracellular medium. This cryo-concentration of solutes induces water transport from the intracellular medium of the cell to the extracellular medium and, thus, leads to cell dehydration and cell injury. At high cooling rates, the formation of intracellular ice would be primarily responsible for the death of different kinds of eukaryote cells (Mazur, 1977; Karlsson et al., 1993). However, no direct evidence of intracellular ice formation in cryopreserved bacteria has been presented. In contrast, it was clearly established that at very high cooling rates, no intracellular ice was formed in LAB, but injuries were caused by cell plasmolysis occurring during thawing (Fonseca et al., 2006). Moreover, at low cooling rates, freeze-fracture electron microscopy highlights dense cell packing in the cryo-concentrated matrix. Therefore, direct contact between cells and ice is extremely reduced, thus allowing the neglect of mechanical damage caused by extracel- 
lular ice crystal constraints and favoring dehydration as the main stress incurred by cells at low cooling rates. Lactic acid bacteria survival during freezing is, thus, highly dependent on the cellular biophysical event of cell dehydration and particularly on the membrane permeability to water. The membrane permeability is influenced by its fluidity property, which is, in turn, governed by the composition and the structure of the lipid bilayer (Stubbs, 1983).

The cell membrane thus plays a fundamental role in the freezing resistance of LAB. Some authors have established a correlation between membrane lipid composition and freeze tolerance of different strains. The viability after cell freezing of $L b$. delbrueckii ssp. bulgaricus increases with the cyclopropane FA concentration in membranes (Smittle et al., 1974) and an increase in the ratio between unsaturated FA (UFA) and SFA is related to an improvement in the cryotolerance of $\mathrm{Lac}$ tococcus lactis ssp. lactis and Lactobacillus spp. (Goldberg and Eschar, 1977) and Streptococcus thermophilus (Beal et al., 2001). The FA composition of the cellular membrane depends upon several environmental factors, including growth temperature, $\mathrm{pH}$, culture medium, and composition, among others. Several researchers have, thus, attempted to modulate the membrane FA composition to improve cryotolerance of LAB by modifying fermentation conditions (Fonseca et al., 2001; Wang et al., 2005; Streit et al., 2007). It is also well established that the cell membrane is one of the primary sites for freezing injuries (Beney and Gervais, 2001; Moussa et al., 2008). However, research is still needed to elucidate the biophysical mechanisms responsible for cell degradation following freezing, and especially to relate them to membrane properties. Previous studies have established that freezing alters the physical state of lipids, thus modifying lipid organization and membrane fluidity (Wolkers et al., 2007; Balasubramanian et al., 2009; Ragoonanan et al., 2010). Biological membranes often exhibit a liquid crystalline-to-gel phase transition during cooling and vice versa during heating (Crowe et al., 1989; Drobnis et al., 1993). The consequences of such lipid phase transition are thought to include increased membrane leakage and lateral phase separation of membrane components (Drobnis et al., 1993; Tablin et al., 2001).

Fourier transform infrared (FTIR) spectroscopy is a suitable technique for studying in situ LAB cells (Oldenhof et al., 2005). Moreover, it has already been used to study freezing- and thawing-induced changes in the membrane lipid bilayer structure of mammalian cells (Oldenhof et al., 2011, 2013). The symmetric $\mathrm{CH}_{2}$ stretching vibrations of lipids are commonly used to detect phase transitions in isolated biological membranes and in whole cells (Crowe et al., 1989; Hoekstra and Golovina, 1999).

The aim of the present work was to relate membrane physical behavior to the freezing resistance of $\mathrm{Lb}$. delbrueckii ssp. bulgaricus CFL1 cells. Two cell populations presenting different lipid membrane compositions and different resistances to freezing were generated by using 2 different culture media. Biological responses of frozenthawed bacterial cells (cultivability, acidifying activity, and membrane integrity) were compared with those of fresh cells. Fourier transform infrared spectroscopy was used to investigate in situ changes in membrane lipid phase behavior of cells during freeze-thawing. The results presented here expand our understanding of the physical events occurring in LAB cell membranes during freeze-thaw cycles and their connection to cell cryoinjury.

\section{MATERIALS AND METHODS}

\section{Materials, Reagents, and Chemicals}

de Man, Rogosa, and Sharpe (MRS) broth and agar, mild whey powder, yeast extract, and skim milk powder were purchased from Biokar Diagnostics (Beauvais, France), Eurosérum (Port-sur-Saône, France), Organotechnie SAS (La Courneuve, France), and EPI Ingredients (Ancenis, France), respectively. Propidium iodide (PI) was obtained from Sigma-Aldrich Chimie S.a.r.l. (Lyon, France).

Diatomaceous earth and cellulose filters were furnished by Dionex (Voisins-le-Bretonneux, France). Sand of 50- to 70-mesh particle size and trimethylsulfonium hydroxide $(0.25 \mathrm{M}$ in methanol) were provided by Sigma-Aldrich Chimie S.a.r.l. Potassium chloride, methanol, and chloroform stabilized with $0.6 \%$ ethanol were supplied by VWR International SAS (Fontenaysous-Bois, France). Solvents were Normapur/analytical grade. Fatty acid standards were purchased either from Sigma-Aldrich Chimie S.a.r.l. or from Interchim (Montluçon, France) with a purity $\geq 99 \%$.

\section{Bacterial Strain and Growth Conditions}

The lactic acid bacterium Lb. delbrueckii ssp. bulgaricus CFL1 was chosen due to its sensitivity to freezing (Fonseca et al., 2000; Rault et al., 2007). It was provided by the Laboratoire de Génie et Microbiologie des Procédés Alimentaires (INRA, Thiverval-Grignon, France). Inocula were stored at $-80^{\circ} \mathrm{C}$ and were thawed for $5 \mathrm{~min}$ before inoculation at $40^{\circ} \mathrm{C}$. Two different culture media [MRS broth (a rich medium) or mild whey-based medium (a less rich medium than MRS)] 
were used to obtain bacterial populations exhibiting different membrane properties. The mild whey medium was composed of $60 \mathrm{~g}$ of whey powder/L and was heated at $110^{\circ} \mathrm{C}$ for $20 \mathrm{~min}$. The supernatant obtained after centrifugation $\left(17,700 \times g\right.$ for $30 \mathrm{~min}$ at $\left.4^{\circ} \mathrm{C}\right)$ and filtration $(330 \mathrm{~mm})$ was supplemented with $5 \mathrm{~g}$ of yeast extract/L. The mild whey medium was then sterilized at $110^{\circ} \mathrm{C}$ for $20 \mathrm{~min}$. The MRS broth was prepared by following the explanations written on the commercial box and sterilized at $118^{\circ} \mathrm{C}$ for $20 \mathrm{~min}$. Preliminary experiments were carried out to determine the kinetics of bacterial growth in both culture media to ensure that the cells were harvested at the end of the exponential phase. Absorbance measurements at $600 \mathrm{~nm}$ were used to follow bacterial growth. These experiments made it possible to define the inoculation rates and the duration of the preculture and culture steps. So, after a preculture of $10 \mathrm{~h}$ in MRS broth at $40^{\circ} \mathrm{C}$ without shaking and with an inoculation at around $10^{8} \mathrm{cfu} / \mathrm{mL}, 10$ $\mathrm{mL}$ and $150 \mu \mathrm{L}$ of preculture were introduced into 300 $\mathrm{mL}$ of MRS broth and mild whey medium, respectively. Lactobacillus delbrueckii ssp. bulgaricus CFL1 was grown without shaking at $40^{\circ} \mathrm{C}$ until the end of the exponential phase was reached $\{10 \mathrm{~h}$ for mild whey medium [specific growth rate $(\mu)=1.3 \mathrm{~h}^{-1}$ ] and $13 \mathrm{~h}$ for MRS broth $\left.\left(\mu=0.4 \mathrm{~h}^{-1}\right)\right\}$. The cell suspensions were then cooled down at $4^{\circ} \mathrm{C}$ in an ice-water bath and harvested by centrifugation $\left(17,700 \times g\right.$ for $10 \mathrm{~min}$ at $\left.4^{\circ} \mathrm{C}\right)$. The cellular pellets obtained either from the MRS or the mild whey cultures were resuspended at $4^{\circ} \mathrm{C}$ in the same weight of a sterile protective medium (i.e., $50 \%$ wt/wt). The protective medium was composed of $20 \%$ (wt/wt) sucrose in saline solution $(8.9 \mathrm{~g}$ of $\mathrm{NaCl} / \mathrm{L})$. These protected bacterial suspensions were used for biological activity assessment and freezing experiments.

\section{Lipid Extraction}

Cellular lipids were extracted by means of accelerated solvent extraction (ASE 350; Dionex). The procedure was adapted from previously described work (Cescut et al., 2011). For each fermentation medium (MRS broth or mild whey medium), 3 cultures were subjected to extraction and for each culture, 3 extractions were performed. At the end of the fermentation, bacterial cells were collected by centrifugation $(17,700 \times g$ for 10 min at $4^{\circ} \mathrm{C}$ ) and washed twice with saline solution at $4^{\circ} \mathrm{C}$. About 0.1 to $0.2 \mathrm{~g}$ of washed pellet was precisely weighed and mixed with $2.0 \mathrm{~g}$ of diatomaceous earth as dispersant and desiccant to improve extraction performance. The mix was introduced into a stainless steel cell $(5 \mathrm{~mL})$. Three extraction cycles using 3 different chloroform/methanol solvent mixtures: $2: 1 ; 1: 1$, and $1: 2$ (vol/vol) were performed. For each solvent mixture, 2 static cycles of 15 min were applied. The extraction solvent was pumped through the extraction cell fitted with a cellulose filter and a stainless steel frit at the outlet. Each stainless steel cell was maintained at a pressure of $10^{7} \mathrm{~Pa}$ and a temperature of $100^{\circ} \mathrm{C}$ throughout the extraction. All resulting extracts of a sample were automatically combined in the same vial. At the end of the extraction, extracts were first evaporated to dryness in a vacuum centrifugal evaporator (RC 10-22) combined to a refrigerated trap (RCT 90; Jouan, SaintHerblain, France), at 1,200 rpm and approximately $55^{\circ} \mathrm{C}$. Dry samples were resuspended in $3 \mathrm{~mL}$ of chloroform and $3 \mathrm{~mL}$ of a potassium chloride solution $[0.88 \%$ (wt/vol) $\mathrm{KCl}]$ was added. After vigorous manual shaking, the extracts were centrifuged (vacuum centrifugal evaporator; $480 \times g$ for $5 \mathrm{~min}$ at $25^{\circ} \mathrm{C}$ ) to separate aqueous and organic phases. The organic phase containing membrane lipids was dried (vacuum centrifugal evaporator; RC 10-22; Jouan, Saint-Herblain, France; $1,200 \mathrm{rpm}$, heating at approximately $55^{\circ} \mathrm{C}$ ). Dry lipids were then resuspended in $300 \mu \mathrm{L}$ of chloroform before GC-MS analysis. Fifty microliters of this solution was mixed with $25 \mu \mathrm{L}$ of internal standard C9:0 and $50 \mu \mathrm{L}$ of methylation reagent trimethylsulfonium hydroxide in vials for GC-MS analysis.

\section{FA Analysis by GC-MS}

Gas chromatography-mass spectrometry analysis was carried out on a Hewlett-Packard 6890 gas chromatograph equipped with a capillary column packed with $70 \%$ cyanopropyl polysilphenylene-siloxane BPX70 (60 $\mathrm{m} \times 0.25 \mathrm{~mm} \times 0.25 \mu \mathrm{m} ;$ SGE Analytical Science Pty Ltd., Victoria, Australia), coupled to a mass selective detector (5973; Agilent Technologies, Avondale, PA). The carrier gas was helium $(1.2 \mathrm{~mL} / \mathrm{min})$ and the column pressure was $1.3 \times 10^{5} \mathrm{~Pa}$. Injection of $1 \mu \mathrm{L}$ of the vial was done splitless at an injector temperature of $250^{\circ} \mathrm{C}$. The oven temperature was held for $1 \mathrm{~min}$ at $35^{\circ} \mathrm{C}$ and then increased from 35 to $100^{\circ} \mathrm{C}$ at $40^{\circ} \mathrm{C} / \mathrm{min}$, held for $1 \mathrm{~min}$ at $100^{\circ} \mathrm{C}$ and then increased from 100 to $130^{\circ} \mathrm{C}$ at $5^{\circ} \mathrm{C} / \mathrm{min}$, followed by an increase from 130 to $180^{\circ} \mathrm{C}$ at $1.5^{\circ} \mathrm{C} / \mathrm{min}$ and finally from 180 to $240^{\circ} \mathrm{C}$ at $5^{\circ} \mathrm{C} / \mathrm{min}$. The detection temperature was $230^{\circ} \mathrm{C}$. The FA methyl esters were first identified by comparison of their retention times with those of known standards. Identification of FA methyl esters was confirmed by using the mass selective detector at a scan rate of 3.14 scans/s, with data collected in the range of 33 to 500 amu. The mass spectra of the FA methyl esters were compared with the data bank Wiley 275.L (HewlettPackard, Gaithersburg, MD). The quantification of FA was calculated on target ions using external calibration performed with serial dilutions of commercial standards, 
with C9:0 as internal standard. As $\Delta$ C19:0 (cyclic FA) could not be found as pure standard, its concentration was approximated using the response coefficient of the C18:1 FA (for which the response coefficient was equal to 0.25$)$. All quantification results were converted into the mass of FA per cell mass unit on a dry basis.

\section{DM of Cell Pellets}

Freshly harvested cell pellets were washed twice with saline solution at $4^{\circ} \mathrm{C}$. About 0.5 to $1 \mathrm{~g}$ of washed pellet was weighed precisely $( \pm 0.1 \mathrm{mg})$ and placed at $104^{\circ} \mathrm{C}$ for $24 \mathrm{~h}$. The dried pellet was weighed again and the DM could be calculated. This was done in triplicate for the 2 cell culture media (MRS broth and mild whey medium).

\section{Freezing Experiments}

Two milliliters of the protected bacterial suspensions was dispersed into $5-\mathrm{mL}$ sterile tubes. Samples were then placed into a freezer at $-80^{\circ} \mathrm{C}$. The temperature inside the samples was monitored with thermocouples (type $\mathrm{T} ; 0.2-\mathrm{mm}$ diameter) to quantify the cooling rate, which was determined as $4^{\circ} \mathrm{C} / \mathrm{min}$. The samples were then stored at $-80^{\circ} \mathrm{C}$ for at least $24 \mathrm{~h}$ before biological analysis. The samples were thawed for $2 \mathrm{~min}$ in a $42^{\circ} \mathrm{C}$ temperature-controlled water bath just before performing analysis.

\section{Analysis of the Biological Activity}

To determine the biological activity of the protected bacterial suspensions before and after freezing, 2 properties were measured: (1) the specific acidifying activity $\left(\mathbf{t}_{\text {spe }}\right)$ and (2) the membrane integrity. The measurements were carried out before and after freezing and thawing on the protected bacterial suspensions.

Specific Acidifying Activity Measurements. The Cinac system (AMS, Frépillon, France) was used to measure the acidifying activity of the protected suspensions of LAB before and after freezing (Spinnler et al., 1989; Picque et al., 1992; Beal et al., 2001). Acidifying activity measurements were performed in triplicate, using reconstituted dry skim milk at $42^{\circ} \mathrm{C}$. The $\mathrm{pH}$ of inoculated milk samples was continuously measured, which allowed the calculation of its first-time derivative, representing the acidifying rate. For each sample, the time necessary to reach the maximum acidifying rate in milk (tm; in min) was used to characterize the acidifying activity of bacterial suspensions. The higher the tm, the longer the latency phase and the lower the acidifying activity was.
Cell concentration $(\mathrm{cfu} / \mathrm{mL}$ ) was evaluated by plate counts. After serial dilutions in saline water, cells were plated onto solid MRS agar and incubated under anaerobic conditions (GENbox 96124; bioMérieux, Marcy l'Étoile, France) at $42^{\circ} \mathrm{C}$ for $48 \mathrm{~h}$ before cell counting. Results corresponded to geometrical means of at least 3 counts.

The $\mathrm{t}_{\text {spe }}[\mathrm{in} \min / \log (\mathrm{cfu} / \mathrm{mL})]$ was defined as the ratio of tm to the corresponding log of the cell concentration (Streit et al., 2007). Consequently, the $t_{\text {spe }}$ give an accurate and meaningful measurement of the biological activity of LAB, including the physiological state and viability. The $t_{\mathrm{spe}}$ was calculated before $\left(\mathrm{t}_{\mathrm{spe}} \mathrm{c}\right.$; in min) and after freezing $\left(t_{\text {spe }} f\right.$; in min). As a result, $d_{\text {spe }}\left(t_{\text {spe }} f\right.$ $-t_{\text {spe }} c$ ) characterized the loss in $t_{\text {spe }}$ during freezing. An increase in the $\mathrm{dt}_{\mathrm{spe}}$ corresponds to an increase of loss in $\mathrm{t}_{\mathrm{spe}}$ during freezing.

Membrane Integrity Measurements. Propidium iodide uptake was successfully used to measure membrane permeabilization by flow cytometry in relation with inactivation kinetics of different microbial strains after various treatments (Ulmer et al., 2000; Wouters et al., 2001; Rault et al., 2007). This probe cannot penetrate within cells having intact membranes but can enter when cell membranes have been damaged. Inside the cells, it binds to the DNA and produces a red fluorescence after excitation at $488 \mathrm{~nm}$. Before staining, cell suspensions of Lb. delbrueckii ssp. bulgaricus CFL1 were diluted in McIlvaine buffer ( $\mathrm{pH} 7.3$ ) to reach approximately $10^{6}$ cells $/ \mathrm{mL}$. The McIlvaine buffer is composed of $0.1 M \mathrm{C}_{6} \mathrm{H}_{8} \mathrm{O}_{7}$ (citric acid) and $0.2 \mathrm{M} \mathrm{Na}_{2} \mathrm{HPO}_{4}$ (sodium phosphate). One milliliter of the diluted suspension was supplemented with $10 \mu \mathrm{L}$ of PI solution (1.5 $\mathrm{m} M$ in distilled water) and then incubated for $10 \mathrm{~min}$ at $40^{\circ} \mathrm{C}$. Fluorescence was measured by flow cytometry using a BactiFlow cytometer (AES Chemunex, Bruz, France). Data were collected and analyzed with FlowMax software (Partec S.a.r.l., Sainte-Geneviève-des-Bois, France). This software allowed the calculation of the percentage of stained cells. The loss in membrane integrity was then evaluated by calculating the difference between the percentage of stained cells after and before freezing (Rault et al., 2007). The lower the difference, the lower the loss in membrane integrity during freezing was. All fluorescence measurements were performed at least in triplicate from independent cultures.

\section{FTIR Spectroscopy Studies}

Infrared absorption measurements were carried out with a Nicolet Magna 750 FTIR spectrometer (Thermo Fisher Scientific, Madison, WI) equipped with a nar- 
row-band mercury/cadmium/telluride (MCT) infrared detector and a Specac variable temperature cell cooled by liquid nitrogen (Specac Ltd., Orpington, Kent, UK). The temperature of the sample was recorded separately using an extra thermocouple that was located close to the sample. The optical bench was continuously purged with dry air (Balston, Haverhill, MA). The acquisition parameters were $4 \mathrm{~cm}^{-1}$ resolution, 32 co-added interferograms, and a 4,000 to $900 \mathrm{~cm}^{-1}$ wavenumber range. Fresh bacterial pellets were washed twice in saline water. The washed bacterial pellet was then sandwiched between $2 \mathrm{CaF}_{2}$ windows. Samples were mounted into the Specac cell. The temperature dependence of the FTIR spectra was studied by cooling the sample from $50^{\circ} \mathrm{C}$ down to $-50^{\circ} \mathrm{C}$ at a rate of $2^{\circ} \mathrm{C} / \mathrm{min}$ and then by heating the sample from -50 to $80^{\circ} \mathrm{C}$ at $2^{\circ} \mathrm{C} / \mathrm{min}$. Experiments were performed 8 times. Spectral analysis and display were carried out using OMNIC software (Thermo Fisher Scientific, Madison, WI).

Following Crowe et al. (1989), membrane phase behavior was monitored by observing the position of the symmetric $\mathrm{CH}_{2}$ stretching band at approximately 2,850 $\mathrm{cm}^{-1}$. To determine the peak location, the secondderivative spectrum analysis was performed with a Savitzky-Golay derivative function of third degree following 9-point smoothing (Savitzky and Golay, 1964) and was then multiplied by -1 . Wavenumber of the symmetric $\mathrm{CH}_{2}$ stretching peak ( $\boldsymbol{\nu} \mathbf{C H}_{2}$ symmetric) versus temperature plots were constructed for freezing and thawing. The plots were fitted with a curve based on an asymmetric sigmoid transition function and the first derivative was calculated. The maximum of the first derivative of the fitted curves was taken as the lipid phase transition temperature (Ts: lipid solidification following freezing; Tm: lipid melting following thawing).

The ice nucleation and melting temperatures were determined by following the peak position of the water libration and bending combination band in the region 2,250 to $2,000 \mathrm{~cm}^{-1}$. The phase change of water into ice leads to a shift to higher wavenumbers due to the changes in hydrogen-bending interactions that occur as water solidifies. Wavenumber of the position of the $\mathrm{H}_{2} \mathrm{O}$-libration and -bending band at approximately $2,200 \mathrm{~cm}^{-1}\left(\nu \mathrm{H}_{2} \mathrm{O}\right)$ versus temperature plots were constructed to determine the ice nucleation and melting temperatures as the onset-temperature at which the $\mathrm{H}_{2} \mathrm{O}$ band shifted to higher values or lower values, respectively.

\section{Statistical Analysis}

Significance of results was assessed at a 95\% confidence level. Statistical tests were carried out using
XLSTAT software (Addinsoft, Paris, France). Exact 2-sample permutation tests were conducted to contrast data obtained from cells cultivated in MRS broth versus data obtained from cells cultivated in mild whey medium.

\section{RESULTS}

\section{Membrane FA Composition of Lb. delbrueckii ssp. bulgaricus CFL1 Cells}

To quantify the physiological changes that are induced by different compositions of culture media (MRS broth or mild whey medium), the membrane FA composition of $L b$. delbrueckii ssp. bulgaricus CFL1 cells was analyzed just after harvesting at the end of the exponential phase. Results are summarized in Table 1. The type and total content of FA were comparable for both culture conditions (13 FA in common of $14 \mathrm{FA}$ found; about $6 \mathrm{mg}$ of $\mathrm{FA} / \mathrm{g}$ of bacteria, dry basis); C16:0 and C18:1 were the 2 major FA for Lb. delbrueckii ssp. bulgaricus CFL1 cell populations, whatever the culture medium. However, marked differences were observed in the membrane FA composition of cells according to these culture conditions. For cells grown in MRS broth, only 3 FA represented more than $80 \%$ of the total FA: C18:1 (48\%), C16:0 (18\%), and $\Delta$ C19:0 (cyclic FA, $14 \%$ ). For cells grown in mild whey-based medium, 5 FA accounted for more than $80 \%$ of the total FA: C16:0 (38\%), C18:1 (22\%), C14:0 (9\%), C16:1 (7\%), and C18:0 (7\%). Cells grown in MRS broth exhibited a higher ratio of UFA:SFA than cells grown in mild whey (1.6 and 0.5, respectively). In addition, $\Delta \mathrm{C} 19: 0$ represents $14 \%$ of the cell FA content for cells grown in MRS broth but only $2 \%$ of the total FA of cells grown in whey medium. Growth in MRS broth permitted cells to enrich significantly their membrane in unsaturated and cyclic FA compared with growth in mild whey.

\section{Freezing Resistance of Lb. delbrueckii ssp. bulgaricus CFL1 Cells}

The $\mathrm{t}_{\mathrm{spe}}[\mathrm{in} \mathrm{min} / \log (\mathrm{cfu} / \mathrm{mL})]$ was determined before and after freezing for both culture conditions. Freezing resistance was assessed by calculating the loss in $t_{\text {spe }}$ $\left[\mathrm{dt}_{\mathrm{spe}}\right.$, in $\left.\mathrm{min} / \log (\mathrm{cfu} / \mathrm{mL})\right]$ following freezing as the difference between $t_{\text {spe }}$ values before and after freezing (Table 2). Cells grown in MRS broth exhibited a significantly lower loss in $t_{\text {spe }}$ during freezing $\left[\mathrm{dt}_{\mathrm{spe}}=2 \mathrm{~min} /\right.$ $\log (\mathrm{cfu} / \mathrm{mL})]$ than cells grown in mild whey medium $\left[\mathrm{dt}_{\mathrm{spe}}=6 \mathrm{~min} / \log (\mathrm{cfu} / \mathrm{mL}) ; P<0.05\right]$. Cells grown in MRS broth appeared, thus, more resistant to freezing than cells grown in mild whey.

Furthermore, when considering the measurement of membrane integrity following freezing, an increase 
Table 1. Fatty acid composition $\left(\mu \mathrm{g} / \mathrm{g}\right.$ of dry pellet and relative percentages; means $\left.\pm \mathrm{SD}^{1}\right)$ in Lactobacillus delbrueckii ssp. bulgaricus CFL1 cells grown in de Man, Rogosa, and Sharpe (MRS) broth or in mild whey medium and harvested at the end of the exponential growth phase

\begin{tabular}{|c|c|c|c|c|}
\hline \multirow[b]{2}{*}{ FA } & \multicolumn{2}{|c|}{ MRS broth } & \multicolumn{2}{|c|}{ Mild whey } \\
\hline & $\mu \mathrm{g} / \mathrm{g}$ & $\%$ & $\mu \mathrm{g} / \mathrm{g}$ & $\%$ \\
\hline C11:0 & $<\mathrm{DL}^{2}$ & & $<\mathrm{DL}$ & \\
\hline $\mathrm{C} 12: 0$ & $<\mathrm{DL}$ & & $184 \pm 19$ & $3 \pm 0.2$ \\
\hline C13:0 & $118 \pm 39$ & $2 \pm 0.1$ & $48 \pm 10$ & $1 \pm 0.2$ \\
\hline C14:0 & $353 \pm 110$ & $5 \pm 0.9$ & $484 \pm 51$ & $9 \pm 0.8$ \\
\hline C15:0 & $111 \pm 17$ & $2 \pm 0.1$ & $97 \pm 14$ & $2 \pm 0.3$ \\
\hline C16:0 & $1,294 \pm 287$ & $18 \pm 1.5$ & $2,146 \pm 378$ & $38 \pm 0.5$ \\
\hline C16:1 & $159 \pm 27$ & $2 \pm 0.5$ & $378 \pm 135$ & $7 \pm 1.8$ \\
\hline $\mathrm{C} 17: 0$ & $18 \pm 2$ & $0 \pm 0$ & $36 \pm 5$ & $0 \pm 0$ \\
\hline C18:0 & $191 \pm 21$ & $3 \pm 0.1$ & $385 \pm 65$ & $7 \pm 0.3$ \\
\hline C18:1 & $3,459 \pm 394$ & $48 \pm 2.3$ & $1,242 \pm 266$ & $22 \pm 3.7$ \\
\hline C18:2 & $235 \pm 92$ & $3 \pm 0.6$ & $223 \pm 3$ & $4 \pm 0.7$ \\
\hline C19:0 & $203 \pm 54$ & $3 \pm 0.1$ & $79 \pm 18$ & $1 \pm 0.3$ \\
\hline$\Delta \mathrm{C} 19: 0$ & $1,023 \pm 20$ & $14 \pm 1.8$ & $119 \pm 43$ & $2 \pm 1.1$ \\
\hline C20:0 & $10 \pm 4$ & $0 \pm 0.1$ & $29 \pm 5$ & $0 \pm 0$ \\
\hline $\mathrm{C} 22: 0$ & $40 \pm 23$ & $0 \pm 0.1$ & $208 \pm 50$ & $4 \pm 0.5$ \\
\hline $\mathrm{C} 18: 2$ conjugated & $<\mathrm{DL}$ & & $<\mathrm{DL}$ & \\
\hline Total SFA & $2,341 \pm 514$ & & $3,698 \pm 584$ & \\
\hline Total UFA ${ }^{3}$ & $3,853 \pm 459$ & & $1,843 \pm 367$ & \\
\hline UFA:SFA & $1.60 \pm 0.17$ & & $0.50 \pm 0.02$ & \\
\hline
\end{tabular}

${ }^{1}$ Data are the averages of 3 separate experiments.

${ }^{2} \mathrm{DL}=$ detection limit.

${ }^{3} \mathrm{UFA}=$ unsaturated FA (cyclic FA $\Delta \mathrm{C} 19: 0$ not included in the UFA).

in the percentage of PI-stained cells was observed for both culture media (Table 2), indicating membrane permeabilization. These results are in agreement with other work reporting membrane permeabilization when the freezing process was applied to yeast and bacteria (Moussa et al., 2008; Cao-Hoang et al., 2010) or sperm cells (Holt et al., 1992; Klimowicz-Bodys et al., 2012). The loss in membrane integrity following freezing was lower for cells grown in MRS broth $(2.8 \%)$ compared with cells grown in whey $(6 \% ; P<0.05)$. Membrane damage following freezing appeared, thus, significantly less important for cells grown in MRS broth than for cells grown in mild whey medium $(P<0.05)$.

Furthermore, the initial acidifying activity $\left(t_{\text {spe }}\right)$ and membrane integrity (\% of PI-stained cells) were different according to the culture conditions. The best cryo- tolerance was observed for cells presenting the highest $\mathrm{t}_{\text {spe }}$ and membrane integrity (MRS broth; Table 2).

\section{FTIR Spectra of Lb. delbrueckii ssp. bulgaricus CFL1 Cells Before and After Freezing}

Figure 1 depicts the infrared absorbance spectra of Lb. delbrueckii ssp. bulgaricus CFL1 pellets obtained at ambient temperature and in the frozen state at $-50^{\circ} \mathrm{C}$ for the 2 culture conditions. The infrared spectra of the cells were dominated by the signal of absorption bands arising from water (either in liquid or in solid state). Water exhibited strong vibrational bands at $3,400 \mathrm{~cm}^{-1}, 2,200 \mathrm{~cm}^{-1}$, and $1,650 \mathrm{~cm}^{-1}$, arising from the combination of stretching, libration and bending, and scissoring vibrational modes, respectively. The

Table 2. Specific acidifying activity $\left[\mathrm{t}_{\mathrm{spe}}\right.$; in $\left.\mathrm{min} / \log (\mathrm{cfu} / \mathrm{mL})\right]$, percentage of propidium iodide (PI)-stained cells determined before and after freezing and losses in specific acidifying activity $\left[\mathrm{dt}_{\mathrm{spe}} ;\right.$ in $\left.\mathrm{min} / \log (\mathrm{cfu} / \mathrm{mL})\right]$ and in membrane integrity during freezing of Lactobacillus delbrueckii ssp. bulgaricus CFL1 grown in de Man, Rogosa, and Sharpe (MRS) broth or in mild whey medium and harvested at the end of the exponential growth phase (data are the means of 3 separate experiments)

\begin{tabular}{lccccc}
\hline & \multicolumn{2}{c}{ MRS broth } & & \multicolumn{2}{c}{ Mild whey } \\
\cline { 2 - 3 } \cline { 5 - 6 } Item & Before freezing & After freezing & & Before freezing & After freezing \\
\hline $\mathrm{t}_{\text {spe }}$ & $14^{\mathrm{a}}$ & $16^{\mathrm{a}}$ & & $29^{\mathrm{b}}$ & $35^{\mathrm{c}}$ \\
$\mathrm{dt}_{\text {spe }}$ & $2.2^{\mathrm{a}}$ & $2^{\mathrm{a}}$ & & $5.4^{\mathrm{b}}$ & $6^{\mathrm{b}}$ \\
\%os PI-stained cells & & $2.8^{\mathrm{a}}$ & & & $11^{\mathrm{c}}$ \\
Loss membrane & & & & $6^{\mathrm{b}}$ \\
\hline
\end{tabular}

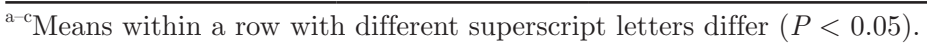


A

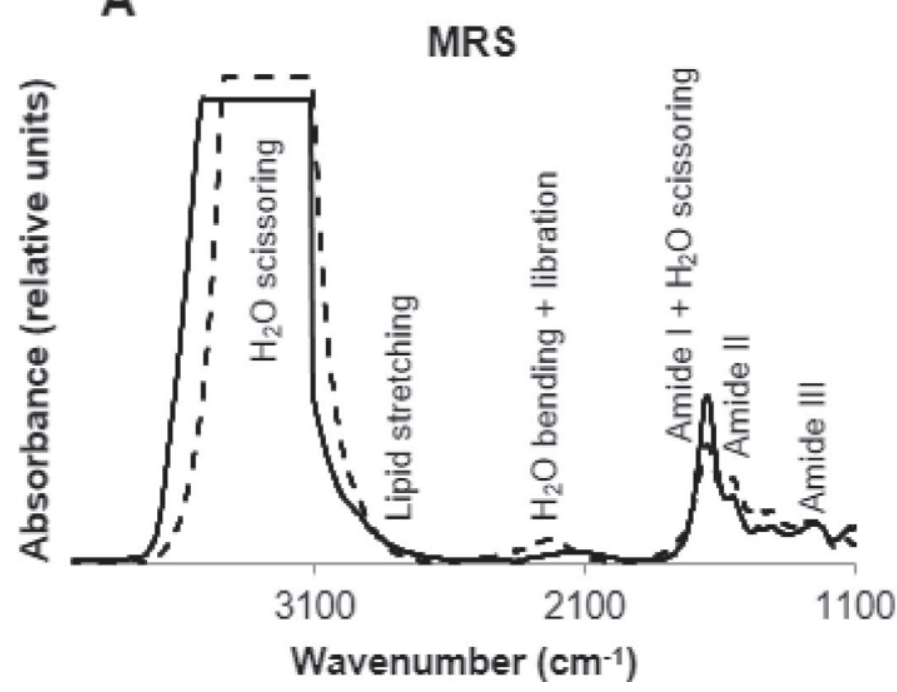

B

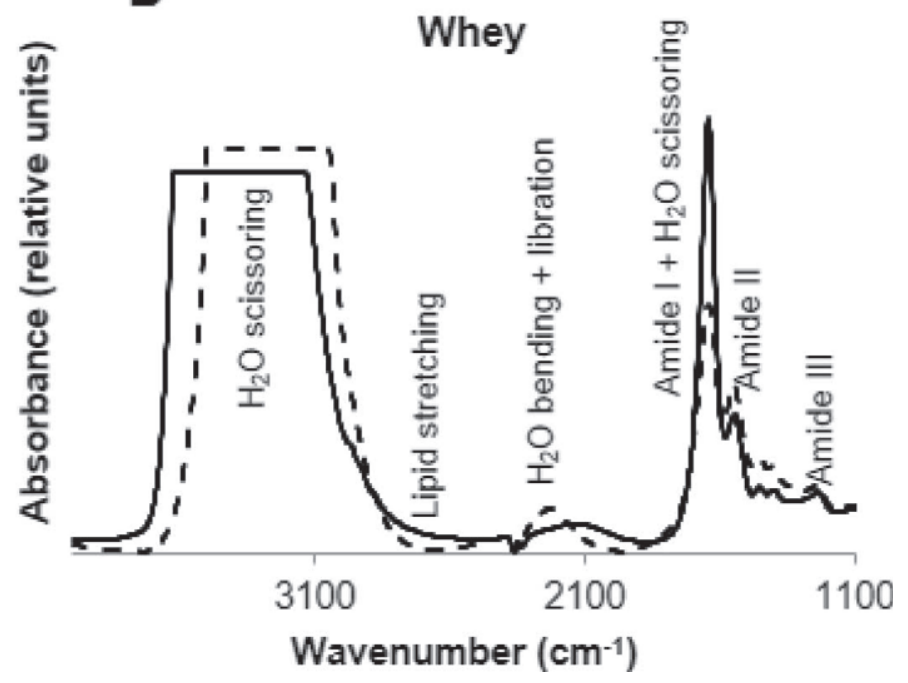

Figure 1. In situ infrared absorption spectra of Lactobacillus delbrueckii ssp. bulgaricus CFL1 cells. Spectra are shown for unfrozen (20 ${ }^{\circ}$, solid line) and frozen $\left(-50^{\circ} \mathrm{C}\right.$, dashed line $)$ cells. Characteristic molecular group vibrations are indicated. MRS $=$ de Man, Rogosa, and Sharpe broth.

band at 3,400 $\mathrm{cm}^{-1}$ appears saturated. At 2,200 $\mathrm{cm}^{-1}$, the frozen sample exhibited clear differences in spectral shape compared with the sample at ambient temperature. This is mostly due to shape changes of the water absorption bands upon transition into ice. In the 3,000 to $2,800 \mathrm{~cm}^{-1}$ region, the symmetric and asymmetric $\mathrm{CH}_{2}$ stretching vibrations of lipid acyl chains were present. Characteristic protein bands were observed at $1,655 \mathrm{~cm}^{-1}$ (amide I), at $1,550 \mathrm{~cm}^{-1}$ (amide II), and at $1,250 \mathrm{~cm}^{-1}$ (amide III).

Because the water band slightly overlaps with the lipid band, water spectra at $20^{\circ} \mathrm{C}$ and $-50^{\circ} \mathrm{C}$ were subtracted from raw spectra at 20 and $-50^{\circ} \mathrm{C}$, respectively (Figures $2 \mathrm{~A}$ and $2 \mathrm{~B}$ ). The subtracted spectra plotted in the 3,000 to $2,800 \mathrm{~cm}^{-1}$ region displayed 4 peaks corresponding to the $\mathrm{CH}$ stretching vibrations of lipids (symmetric and asymmetric $\mathrm{CH}_{3}$ stretching vibrations at 2,958 and $2,872 \mathrm{~cm}^{-1}$, respectively, and symmetric and asymmetric $\mathrm{CH}_{2}$ stretching vibrations at 2,925 and $2,852 \mathrm{~cm}^{-1}$, respectively). The symmetric $\mathrm{CH}_{2}$ stretching vibration is currently used to follow lipid phase transition (Crowe et al., 1989; Leslie et al., 1995; Tablin et al., 2001). For accurately determining the peak positions of lipids, the second derivative was calculated (Figures 2C and 2D). The shift of the symmetric $\mathrm{CH}_{2}$ stretching peak toward lower wavenumbers can be clearly observed between the unfrozen and frozen samples.

\section{FTIR Assessment of the Lipid Membrane Phase Behavior During Freezing and Thawing}

Fourier transform infrared spectroscopy was used to characterize changes in the membrane phase behavior during freezing and thawing. Spectra were acquired during cooling of cell pellets from 50 to $-50^{\circ} \mathrm{C}$, with a cooling rate of $2^{\circ} \mathrm{C} / \mathrm{min}$ (Figures $3 \mathrm{~A}$ and $3 \mathrm{~B}$ ) and during heating from -50 to $80^{\circ} \mathrm{C}$, with a heating rate of $2^{\circ} \mathrm{C} / \mathrm{min}$ (Figures $3 \mathrm{C}$ and $3 \mathrm{D}$ ). Changes in the position of the $\mathrm{H}_{2} \mathrm{O}$ libration and bending combination band and in the lipid symmetric $\mathrm{CH}_{2}$ stretching band were determined and plotted as a function of the sample temperature to assess water phase transition and membrane phase behavior of bacterial cells, respectively.

Ice formation was visible during cooling as an abrupt increase in the water band position $\left(\nu \mathrm{H}_{2} \mathrm{O}\right)$ from around 2,140 to $2,200 \mathrm{~cm}^{-1}$, which occurred spontaneously at around $-11^{\circ} \mathrm{C}$ for both culture conditions (Figures $3 \mathrm{~A}$ and $3 \mathrm{~B})$. During heating, an abrupt decrease in the water band position was conversely observed associated with ice melting at around $-2^{\circ} \mathrm{C}$ (Figures $3 \mathrm{C}$ and $3 \mathrm{D}$ ). A significant degree of supercooling, which corresponds to the difference between the ice melting temperature and the ice nucleation temperature, was obtained during the freezing experiments $\left(9^{\circ} \mathrm{C}\right)$.

The membrane phase behavior was monitored by tracking the shift in the wavenumber position of the symmetric $\mathrm{CH}_{2}$ stretching band at approximately 2,850 $\mathrm{cm}^{-1}\left(\nu \mathrm{CH}_{2}\right.$ symmetric) with cooling and subsequent heating. Considering both culture media, a shift in $\nu \mathrm{CH}_{2}$ symmetric from $2,854 \mathrm{~cm}^{-1}$ to lower wavenumbers $\left(2,851 \mathrm{~cm}^{-1}\right.$ for MRS broth and $2,850 \mathrm{~cm}^{-1}$ for mild whey medium) was observed with decreasing temperature (Figures 3A and 3B). This decrease in wavenumbers denotes membrane phase transition from a relatively disordered fluid lipid phase, called the liquid crystalline phase, to an ordered rigid lipid phase, 



Figure 2. (A and B) Fourier transform infrared (FTIR) absorption spectra after subtraction of the water spectrum of unfrozen $\left(20^{\circ} \mathrm{C}\right.$, solid line) and frozen $\left(-50^{\circ} \mathrm{C}\right.$, dashed line) Lactobacillus delbrueckii ssp. bulgaricus CFL1 cells in the lipid region $\left(3,000-2,800 \mathrm{~cm}^{-1}\right)$. Arrows indicate the different lipid stretching vibrations occurring in this region: $\mathrm{CH}_{3}$ symmetric $\left(\mathrm{CH}_{3}\right.$ sym) and asymmetric $\left(\mathrm{CH}_{3}\right.$ asym) and $\mathrm{CH}_{2}$ symmetric $\left(\mathrm{CH}_{2}\right.$ sym $)$ and asymmetric $\left(\mathrm{CH}_{2}\right.$ asym). (C and D) The second-derivative profile of previous spectra in the 2,900 to $2,800 \mathrm{~cm}^{-1}$ region was included to highlight the decrease in wavenumber of the symmetric $\mathrm{CH}_{2}$ stretching band during freezing. MRS = de Man, Rogosa, and Sharpe broth.

called the gel phase. Changes in frequency are known to reflect isomerization events in the hydrocarbon chains that occur as the lipids are transformed from straight chains, predominantly gauche conformation in liquid crystalline fluid phase to trans conformation in the gel phase (Crowe et al., 1989). The first derivative of the $\nu \mathrm{CH}_{2}$ symmetric versus temperature curve was plotted for the determination of the lipid phase transition temperature during freezing $(\mathrm{Ts})$ and is also represented in Figures 3A and 3B. Cells grown in MRS broth exhibited a lower Ts value $\left(-8^{\circ} \mathrm{C} \pm 4^{\circ} \mathrm{C}\right)$ than cells grown in mild whey medium $\left(22^{\circ} \mathrm{C} \pm 5^{\circ} \mathrm{C}\right)$ during freezing. Furthermore, when considering the MRS culture conditions, it clearly appears in Figure 2A that membrane lipid phase transition occurred simultaneously with ice nucleation in a quite narrow temperature range $\left(21^{\circ} \mathrm{C}\right)$ during cell freezing. Conversely, for cells grown in mild whey medium (Figure 3B), the membrane had already reached the gel phase, a rigid ordered phase when ice nucleation occurred, and the membrane lipid phase transition took place over a broad temperature range (more than $50^{\circ} \mathrm{C}$ ). In addition, cells grown in MRS 

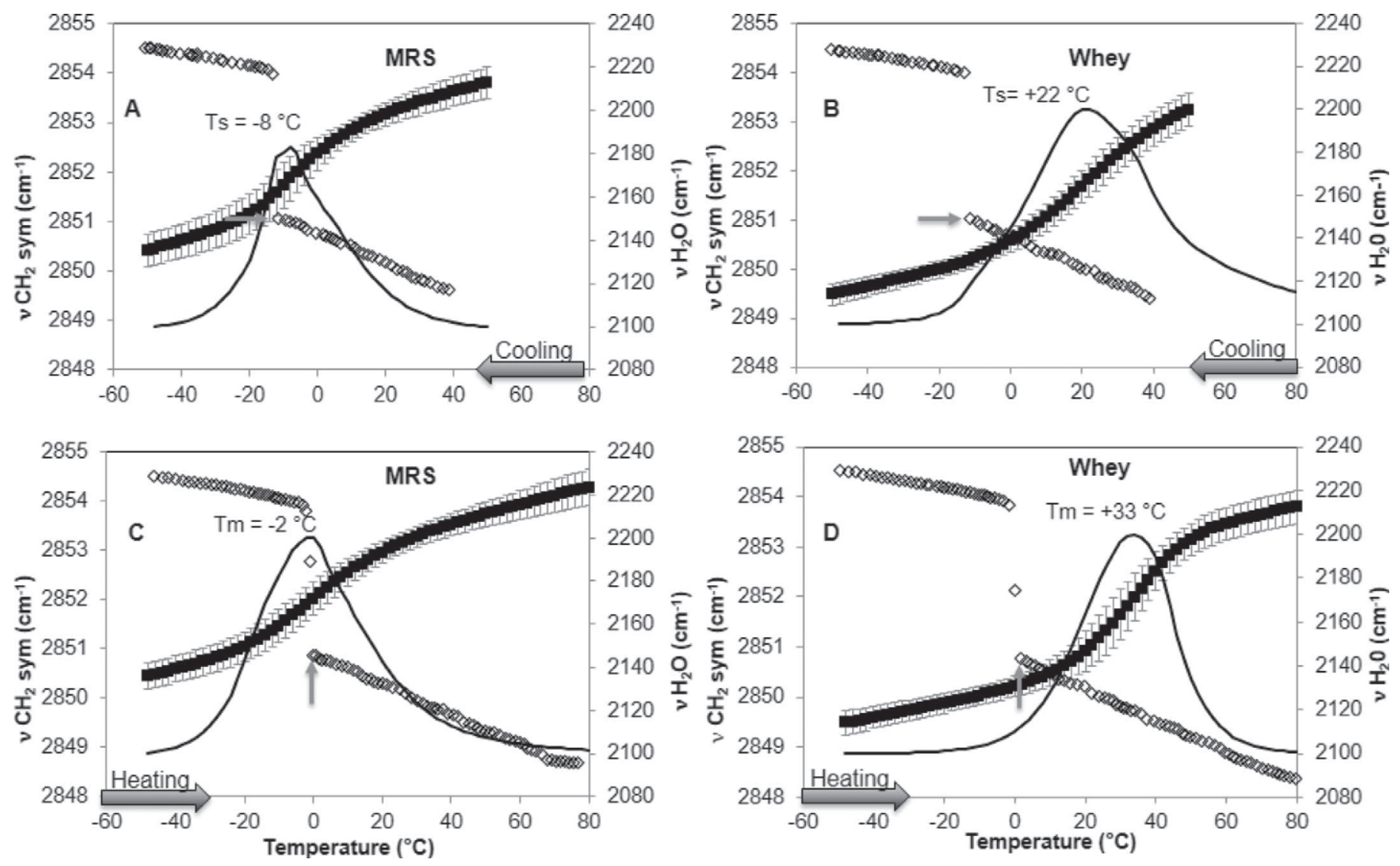

Figure 3. Membrane lipid phase behavior $\left(\mathrm{CH}_{2}\right.$ symmetric) and ice nucleation/melting $\left(\diamond \mathrm{H}_{2} \mathrm{O}\right)$ versus temperature plots of Lactobacillus delbrueckii ssp. bulgaricus CFL1 cells after culture in de Man, Rogosa, and Sharpe (MRS) broth (A and C) or in whey (B and D). Cells were frozen from $50^{\circ} \mathrm{C}$ to $-50^{\circ} \mathrm{C}\left(\mathrm{A}\right.$ and $\mathrm{B}$ ) and they were heated from $-50^{\circ} \mathrm{C}$ to $80^{\circ} \mathrm{C}\left(\mathrm{C}\right.$ and $\mathrm{D}$ ) at $2^{\circ} \mathrm{C} /$ min. The maximum of the first derivative of the wavenumber of the symmetric $\mathrm{CH}_{2}$ stretching peak $\left(\nu \mathrm{CH}_{2}\right)$ versus temperature plot (solid line) allows the determination of the lipid phase transition temperature (Ts: lipid solidification following freezing; Tm: lipid melting following heating). Vertical arrows indicate the ice nucleation temperatures and horizontal arrows the ice melting temperatures. All represented spectra are the averages of 8 separate experiments. Error bars represent the SD of the 8 experiments. $\nu \mathrm{H}_{2} \mathrm{O}$ corresponds to the position of the $\mathrm{H}_{2} \mathrm{O}$-libration and -bending combination band.

broth showed a higher wavenumber of the symmetric $\mathrm{CH}_{2}$ stretching vibration in the frozen state than cells grown in mild whey medium $\left(2,850.5 \mathrm{~cm}^{-1}\right.$ and $2,849.5$ $\mathrm{cm}^{-1}$, respectively). This suggests that even in the gel phase region, a less rigid membrane (less conformational order) was obtained in the frozen state in the case of cells grown in MRS broth than in the case of cells grown in mild whey medium.

Figures $3 \mathrm{C}$ and $3 \mathrm{D}$ represent the membrane phase behavior during thawing, as usually reported in the literature (Crowe et al., 1989; Leslie et al., 1995; Oldenhof et al., 2005). When comparing the $\nu \mathrm{CH}_{2}$ symmetric curves for cells cultivated in MRS broth during cooling (Figure 3A) and heating (Figure 3C) no significant difference was observed in membrane behavior $\left(\mathrm{Tm}=-2 \pm 5^{\circ} \mathrm{C}\right)$. However, a shift of the lipid phase transition temperature to a higher value was observed during thawing of cells grown in mild whey $\left(\mathrm{Tm}=33 \pm 5^{\circ} \mathrm{C}\right)$.

\section{DISCUSSION}

The cell membrane is a critical site of damage during cryopreservation. Freezing induces membrane permeabilization, which can result in cell death. Many studies have already related the lipid membrane composition to the stress adaptation and the improvement of the cell's freezing resistance, in particular for LAB (Smittle et al., 1974; Beal et al., 2001; Streit et al., 2007). However, to our knowledge, no study has investigated the complex biophysical behavior of membranes of LAB during freezing and thawing relative to both the membrane FA composition and integrity and the resulting freezing resistance.

Cells grown in MRS broth, a complex medium leading to freeze-resistant cells, exhibited a higher UFA:SFA ratio (1.6) and content of $\Delta \mathrm{C} 19: 0$ cyclic FA (14\%) than cells grown in mild whey medium $(0.5$ and $2 \%$, respectively). These results are in agreement with previous 
studies reporting a positive relationship between high levels of unsaturated and cyclic FA and the cryoresistance of LAB (Gómez Zavaglia et al., 2000; Beal et al., 2001; Wang et al., 2005). By adding UFA, such as oleic acid derivatives, to the culture medium, it is possible to promote the synthesis of high contents of unsaturated and cyclic FA (Johnson and Etzel, 1995; Muller et al., 2011). The addition of Tween 80 (oleic acid derivative) has proved to enhance the resistance of $L b$. delbrueckii ssp. bulgaricus (Smittle et al., 1974; Fonseca et al., 2001) and Strep. thermophilus (Beal et al., 2001) to freezing. Furthermore, the UFA:SFA ratio is commonly used for assessing membrane fluidity (Beal et al., 2001; Denich et al., 2003; Tymczyszyn et al., 2005). A high UFA:SFA ratio is usually associated with high membrane fluidity. Membranes of cells grown in MRS broth would, thus, be more fluid than those of cells grown in whey. In addition, the $\Delta$ C19:0 cyclic FA is often associated with increasing membrane fluidity and freezing resistance of LAB (Smittle et al., 1974; Gómez Zavaglia et al., 2000; Wang et al., 2005). Even if its role is still poorly understood, its chemical structure suggests that it can act in a comparable way to cis C18:1 FA. These results confirmed that modulating the membrane lipid composition can induce LAB cryotolerance.

The phase behavior in cellular membranes of both bacterial populations exhibiting different lipid compositions and concomitant different freezing resistances was investigated by FTIR spectroscopy. The position of the lipid symmetric $\mathrm{CH}_{2}$ stretching vibration band around $2,850 \mathrm{~cm}^{-1}$ is a measure of membrane lipid state generally related to membrane fluidity. Whatever the culture medium used (MRS broth or mild whey medium), membranes exhibited a liquid crystalline-togel phase transition during cooling and vice versa during warming but significant differences in membrane biophysical behaviors were observed. Freeze-tolerant cells grown in MRS medium exhibited a low value of Tm $\left(-2^{\circ} \mathrm{C}\right.$ during thawing $)$. Similarly, Lactobacillus plantarum, which is reported to be a freeze-resistant bacterium (Dumont et al., 2004), also presented a low Tm value $\left(4^{\circ} \mathrm{C}\right)$ when cultivated in enriched MRS broth (Linders et al., 1997). It has been demonstrated that Tm values depend on the saturation level of the cytoplasmic membrane (Murata, 1989). The low value of lipid phase transition temperature observed for cells grown in MRS broth can be originated from the high content of UFA observed in their membrane. Unsaturated fatty acids have low melting points, thus lowering the Tm of cell lipid membranes. In addition, cyclic FA ( $\Delta$ C19:0), which was observed in high content for cells grown in MRS broth, may also contribute to lower the Tm value of cells. Perly et al. (1985) showed that the introduction of a cyclopropane ring in the membrane model led to a reduction in Tm values. Conversely, for cells grown in mild whey, a lipid membrane phase transition at high positive temperatures was observed (Tm $=+33^{\circ} \mathrm{C}$ during thawing), confirming previous work on Lb. delbrueckii ssp. bulgaricus CFL1 (Oldenhof et al., 2005). The presence of a high content of SFA could, thus, explain the high value of lipid phase transition temperature obtained in the current study.

The freezing resistance of $L b$. delbrueckii ssp. bulgaricus CFL1 grown in MRS broth could, thus, be ascribed to a lipid phase transition occurring at subzero temperatures and overlapping with ice nucleation, which is induced by a high content of unsaturated and cyclic FA in the cell membrane. However, focusing only on the temperature value of the membrane lipid phase transition is not enough for complete characterization of the membrane biophysical behavior during freezing. Furthermore, the in situ and in-real-time FTIR study of the freezing event allows the proposal of 2 major biophysical mechanisms for explaining cell membrane permeabilization observed following freezing: cell dehydration and membrane lipid lateral phase separation.

We have already showed that $L b$. delbrueckii ssp. bulgaricus CFL1 survival during freezing and thawing is highly sensitive to the cellular biophysical event of cell dehydration (Fonseca et al., 2006). Extracellular ice formation occurring after ice nucleation exposes cells to high solute concentrations (osmotic stress) and leads to cell dehydration and volume contraction of cells (mechanical stress; Mazur, 1984). Although similar nucleation ice temperatures were observed for cells grown in MRS broth and in mild whey medium, the biophysical state of their membrane was completely different when the nucleation event took place. In the case of cells grown in MRS broth, the ice formation and melting overlapped with the membrane phase transition. Consequently, when ice nucleated and cells started to dehydrate, the cell membranes were in a fluid and flexible state. Water could leave cells freely and cell volume reduction could occur easily. Moreover, the high content of UFA and SFA resulted in high membrane fluidity, facilitating cell responses to environmental changes all over the freeze-thaw process. Conversely, the membrane of cells grown in mild whey medium had reached a rigid and ordered state when ice nucleation occurred. Cells were, thus, subjected to important mechanical constraints following water escape from the cell and the resulting cell shrinkage. Membrane leakage could then take place for facilitating water flux escape from cell. Actually, this explanation was supported by the high loss of membrane integrity of cells grown in mild whey.

In addition to cell dehydration, the cell membrane undergoes successive phase transitions from the liquid 
crystalline to the gel states during freezing and from the gel to the liquid crystalline states during thawing. Following lipid membrane transition, the presence of several FA within the lipid membrane generally results in local transitions, generating in turn, lateral lipid phase separation with packing effects and changes in lipid-protein interactions (Beney and Gervais, 2001; Tymczyszyn et al., 2005). This phenomenon of lateral phase separation could lead to membrane permeabilization and leakage. The membrane phase transition of cells grown in mild whey medium occurred over a broader temperature range (around $50^{\circ} \mathrm{C}$ ) than cells grown in MRS broth $\left(21^{\circ} \mathrm{C}\right)$ during freezing. The presence within the membrane of cells grown in mild whey medium of 5 major FA ( $80 \%$ of total FA), exhibiting different successive lipid phase transition temperature values, could be responsible for promoting important lateral phase separation and, thus, lengthening the lipid membrane phase transition and shifting Tm to higher values upon thawing. This is consistent with the higher membrane permeabilization observed following freezing. The lower resistance to freeze-thawing of $L b$. delbrueckii ssp. bulgaricus cells grown in whey-based medium can, thus, be attributed to a combination of membrane deformations caused by volumetric contractions and structural changes in membrane lipids during a long phase transition, leading to packing effects and loss of membrane integrity.

\section{CONCLUSIONS}

The present study reported the biophysical characterization by FTIR spectroscopy of LAB cell membrane behavior following freezing and thawing. It was demonstrated that the modulation of the membrane lipid composition has substantial influence on membrane biophysical properties. The differences observed in cell resistance to freezing were related to the lipid phase transition. The best resistance to freezing of $L b$. delbrueckii ssp. bulgaricus CFL1 was mainly associated with the presence of unsaturated and cyclic FA in the membrane, which in turn, lowered the lipid membrane phase transition temperature and consequently made it possible to maintain high membrane fluidity all along the freeze-thawing process.

\section{ACKNOWLEDGMENTS}

This study was supported by the National Institute of Agronomic Research (Paris, France). We thank M. Donald White (ABIES School, Paris, France) for English corrections.

\section{REFERENCES}

Balasubramanian, S. K., W. F. Wolkers, and J. C. Bischof. 2009. Membrane hydration correlates to cellular biophysics during freezing in mammalian cells. Biochim. Biophys. Acta 1788:945-953.

Beal, C., F. Fonseca, and G. Corrieu. 2001. Resistance to freezing and frozen storage of Streptococcus thermophilus is related to membrane fatty acid composition. J. Dairy Sci. 84:2347-2356.

Beney, L., and P. Gervais. 2001. Influence of the fluidity of the membrane on the response of microorganisms to environmental stresses. Appl. Microbiol. Biotechnol. 57:34-42.

Cao-Hoang, L., F. Dumont, P. Marechal, and P. Gervais. 2010. Inactivation of Escherichia coli and Lactobacillus plantarum in relation to membrane permeabilization due to rapid chilling followed by cold storage. Arch. Microbiol. 192:299-305.

Cescut, J., E. Severac, C. Molina-Jouve, and J.-L. Uribelarrea. 2011. Optimizing pressurized liquid extraction of microbial lipids using the response surface method. J. Chromatogr. A 1218:373-379.

Crowe, J. H., F. A. Hoekstra, L. M. Crowe, T. J. Anchordoguy, and E. Drobnis. 1989. Lipid phase transitions measured in intact cells with Fourier transform infrared spectroscopy. Cryobiology 26:7684.

Denich, T. J., L. A. Beaudette, H. Lee, and J. T. Trevors. 2003. Effect of selected environmental and physico-chemical factors on bacterial cytoplasmic membranes. J. Microbiol. Methods 52:149-182.

Drobnis, E. Z., L. M. Crowe, T. Berger, T. J. Anchordoguy, J. W. Overstreet, and J. H. Crowe. 1993. Cold shock damage is due to lipid phase transitions in cell membranes: A demonstration using sperm as a model. J. Exp. Zool. 265:432-437.

Dumont, F., P.-A. Marechal, and P. Gervais. 2004. Cell size and water permeability as determining factors for cell viability after freezing at different cooling rates. Appl. Environ. Microbiol. 70:268-272.

Fonseca, F., C. Béal, and G. Corrieu. 2000. Method of quantifying the loss of acidification activity of lactic acid starters during freezing and frozen storage. J. Dairy Res. 67:83-90.

Fonseca, F., C. Beal, and G. Corrieu. 2001. Operating conditions that affect the resistance of lactic acid bacteria to freezing and frozen storage. Cryobiology 43:189-198.

Fonseca, F., C. Béal, F. Mihoub, M. Marin, and G. Corrieu. 2003. Improvement of cryopreservation of Lactobacillus delbrueckii ssp. bulgaricus CFL1 with additives displaying different protective effects. Int. Dairy J. 13:917-926.

Fonseca, F., M. Marin, and G. J. Morris. 2006. Stabilization of frozen Lactobacillus delbrueckii ssp. bulgaricus in glycerol suspensions: Freezing kinetics and storage temperature effects. Appl. Environ. Microbiol. 72:6474-6482.

Goldberg, I., and L. Eschar. 1977. Stability of lactic acid bacteria to freezing as related to their fatty acid composition. Appl. Environ. Microbiol. 33:489-496.

Gómez Zavaglia, A., E. A. Disalvo, and G. L. De Antoni. 2000. Fatty acid composition and freeze-thaw resistance in lactobacilli. J. Dairy Res. 67:241-247.

Hoekstra, F. A., and E. A. Golovina. 1999. Membrane behavior during dehydration: Implications for desiccation tolerance. Russ. J. Plant Physiol. 46:295-306.

Holt, W. V., M. F. Head, and R. D. North. 1992. Freeze-induced membrane damage in ram spermatozoa is manifested after thawing: Observations with experimental cryomicroscopy. Biol. Reprod. 46:1086-1094.

Johnson, J. A. C., and M. R. Etzel. 1995. Properties of Lactobacillus helveticus CNRZ-32 attenuated by spray-drying, freeze-drying, or freezing. J. Dairy Sci. 78:761-768.

Karlsson, J. O. M., E. G. Cravalho, and M. Toner. 1993. Intracellular ice formation: Causes and consequences. Cryo Lett. 14:323-335.

Klimowicz-Bodys, M. D., F. Batkowski, A. S. Ochrem, and M. A Savič. 2012. Comparison of assessment of pigeon sperm viability by contrast-phase microscope (eosin-nigrosin staining) and flow cytometry (SYBR-14/propidium iodide (PI) staining) [evaluation of pigeon sperm viability]. Theriogenology 77:628-635. 
Leslie, S. B., E. Israeli, B. Lighthart, J. H. Crowe, and L. M. Crowe. 1995. Trehalose and sucrose protect both membranes and proteins in intact bacteria during drying. Appl. Environ. Microbiol. 61:3592-3597.

Linders, L. J. M., G. Meerdink, and K. Van 't Riet. 1997. Effect of growth parameters on the residual activity of Lactobacillus plantarum after drying. J. Appl. Microbiol. 82:683-688.

Mazur, P. 1977. The role of intracellular freezing in the death of cells cooled at supraoptimal rates. Cryobiology 14:251-272.

Mazur, P. 1984. Freezing of living cells: Mechanisms and implications. Am. J. Physiol. 247:C125-C142.

Mazur, P., S. P. Leibo, and E. H. Y. Chu. 1972. A two-factor hypothesis of freezing injury: Evidence from Chinese hamster tissueculture cells. Exp. Cell Res. 71:345-355.

Moussa, M., F. Dumont, J. M. Perrier-Cornet, and P. Gervais. 2008. Cell inactivation and membrane damage after long-term treatments at sub-zero temperature in the supercooled and frozen states. Biotechnol. Bioeng. 101:1245-1255.

Muller, J. A., R. P. Ross, W. F. H. Sybesma, G. F. Fitzgerald, and C. Stanton. 2011. Modification of the technical properties of Lactobacillus johnsonii NCC 533 by supplementing the growth medium with unsaturated fatty acids. Appl. Environ. Microbiol. 77:68896898.

Murata, N. 1989. Low-temperature effects on cyanobacterial membranes. J. Bioenerg. Biomembr. 21:61-75.

Oldenhof, H., A.-K. Blässe, W. F. Wolkers, H. Bollwein, and H. Sieme. 2011. Osmotic properties of stallion sperm subpopulations determined by simultaneous assessment of cell volume and viability. Theriogenology 76:386-391.

Oldenhof, H., M. Gojowsky, S. Wang, S. Henke, C. Yu, K. Rohn, W. F. Wolkers, and H. Sieme. 2013. Osmotic stress and membrane phase changes during freezing of stallion sperm: Mode of action of cryoprotective agents. Biol. Reprod. http://dx.doi.org/10.1095/ biolreprod.112.104661.

Oldenhof, H., W. F. Wolkers, F. Fonseca, S. Passot, and M. Marin. 2005. Effect of sucrose and maltodextrin on the physical properties and survival of air-dried Lactobacillus bulgaricus: An in situ Fourier transform infrared spectroscopy study. Biotechnol. Prog. 21:885-892.

Perly, B., I. C. P. Smith, and H. C. Jarrell. 1985. Effects of the replacement of a double bond by a cyclopropane ring in phosphatidylethanolamines: A deuterium NMR study of phase transitions and molecular organization. Biochemistry 24:1055-1063.

Picque, D., B. Perret, E. Latrille, and G. Corrieu. 1992. Characterization and classification of lactic acid bacteria based on the acidification kinetic. Lebenson. Wiss. Technol. 25:181-186.

Ragoonanan, V., A. Hubel, and A. Aksan. 2010. Response of the cell membrane-cytoskeleton complex to osmotic and freeze/thaw stresses. Cryobiology 61:335-344.
Rault, A., C. Béal, S. Ghorbal, J.-C. Ogier, and M. Bouix. 2007. Multiparametric flow cytometry allows rapid assessment and comparison of lactic acid bacteria viability after freezing and during frozen storage. Cryobiology 55:35-43.

Rault, A., M. Bouix, and C. Béal. 2010. Cryotolerance of Lactobacillus delbrueckii subsp. bulgaricus CFL1 is influenced by the physiological state during fermentation. Int. Dairy J. 20:792-799.

Savitzky, A., and M. J. E. Golay. 1964. Smoothing and differentiation of data by simplified least squares procedures. Anal. Chem. $36: 1627-1639$.

Smittle, R. B., S. E. Gilliland, M. L. Speck, and W. M. Walter Jr. 1974. Relationship of cellular fatty acid composition to survival of Lactobacillus bulgaricus in liquid nitrogen. Appl. Microbiol. $27: 738-743$

Spinnler, H. E., A. Rozzi, C. Béal, and G. Corrieu. 1989. On-line measurement of urease activity to estimate a population of Streptococcus thermophilus in pure and mixed culture. Process Biochem. 24:187-193.

Streit, F., G. Corrieu, and C. Béal. 2007. Acidification improves cryotolerance of Lactobacillus delbrueckii ssp. bulgaricus CFL1. J. Biotechnol. 128:659-667.

Stubbs, C. D. 1983. Membrane fluidity: Structure and dynamics of membrane-lipids. Essays Biochem. 19:1-39.

Tablin, F., W. F. Wolkers, N. J. Walker, A. E. Oliver, N. M. Tsvetkova, K. Gousset, L. M. Crowe, and J. H. Crowe. 2001. Membrane reorganization during chilling: implications for long-term stabilization of platelets. Cryobiology 43:114-123.

Tymczyszyn, E. E., A. Gómez-Zavaglia, and E. A. Disalvo. 2005. Influence of the growth at high osmolality on the lipid composition, water permeability and osmotic response of Lactobacillus bulgaricus. Arch. Biochem. Biophys. 443:66-73.

Ulmer, H. M., M. G. Gänzle, and R. F. Vogel. 2000. Effects of high pressure on survival and metabolic activity of Lactobacillus plantarum TMW1.460. Appl. Environ. Microbiol. 66:3966-3973.

Wang, Y., G. Corrieu, and C. Béal. 2005. Fermentation pH and temperature influence the cryotolerance of Lactobacillus acidophilus RD758. J. Dairy Sci. 88:21-29.

Wolkers, W. F., S. K. Balasubramanian, E. L. Ongstad, H. C. Zec and J. C. Bischof. 2007. Effects of freezing on membranes and proteins in LNCaP prostate tumor cells. Biochim. Biophys. Acta 1768:728-736.

Wouters, P. C., A. P. Bos, and J. Ueckert. 2001. Membrane permeabilization in relation to inactivation kinetics of Lactobacillus species due to pulsed electric fields. Appl. Environ. Microbiol. 67:30923101 . 